\title{
PERKEMBANGAN ETNOPRENEURSHIP DI GARUT 1945-2010
}

\author{
Oleh Iim Imadudin \\ Balai Pelestarian Sejarah dan Nilai Tradisional Bandung \\ Jl. Cinambo No.136 Telp./Fax (022) 7804942 \\ Ujung Berung - Bandung 42094 \\ email: iim.imadudin@yahoo.com
}

Naskah diterima: 3 Juni 2011

Naskah disetujui: 1 Juli 2011

\begin{abstract}
Abstrak
Semangat kewirausahaan dalam konteks kesukubangsaan masih sedikit mendapat perhatian. Minimnya perhatian tersebut terbatas pada etnis-etnis tertentu saja yang dikenal memiliki jiwa etnopreneurship. Penelitian ini berupaya memberikan gambaran bahwa dinamika internal sukubangsa Sunda yang tinggal di Garut memperlihatkan wataknya yang entrepreneurship. Selama ini Garut lebih banyak dikenal sebagai wilayah dengan kekayaan alam yang potensial sehingga menjadi daerah tujuan wisata yang penting. Selain itu, kekayaan kuliner juga sudah menjadi pengetahuan bersama masyarakat Jawa Barat pada khususnya. Sementara itu, pengembangan sumber daya manusia dalam konteks kultural jarang diungkap. Kekhasan ekonomi kreatif di daerah ini terletak pada spesialisasi profesi masingmasing desa. Meski masih terlalu dini, agaknya konsep one village, one product (satu kampung, satu produk) cukup tepat ditempatkan dalam konteks kewirausahaan di Garut. Tradisi merantau secara terbatas menunjukkan karakter khas masyarakat di wilayah Garut. Ada yang menetap dalam waktu yang cukup lama di wilayah lain. Akan tetapi, sebagian terbesar kembali pada waktu-waktu tertentu, bahkan menjadi comutter secara intensif.

Penelitian ini mencakup tiga bidang usaha yang berbeda, yaitu usaha batik garutan, industri kulit Sukaregang, dan tukang cukur Banyuresmi. Ketiga objek telitian tersebut dipetakan menurut dua kategori: kota-desa, surplus-minus. Sumber primer berasal dari wawancara lisan dengan para informan yang terlibat dengan aktivitas kewirausahaan. Sementara itu, sumber sekunder dari literatur. Kajian mengenai semangat kewirausahaan dalam konteks kesukubangsaan menjadi penting di tengah usaha untuk mengembangkan local genious di bidang ekonomi kreatif.
\end{abstract}

Kata kunci: etnopreneurship, sukubangsa, Garut 


\section{Abstract}

The paper was based on the fact that exposing cultural context of human resources is not common in our country. This research tries to describe the great entrepreneurship of the Sundanese of Garut. They used to wander about (merantau) and commute very intensively to trade to other cities or regions. The uniqueness of the city is that every village has its own specialty. This research covers three kinds of business: batik garutan (a kind of batik with spesific motifs of Garut), leather industry in Sukaregang and barbers of Banyuresmi. Data were collected through interviews and bibliographic studies. The author came into conclusion that the study of entrepreneurship (in ethnical context) is very important in developing local genius in creative economy.

Keywords: etnopreneurship, ethnic, Garut

\section{A. PENDAHULUAN}

Sejak tahun 1920-an, Garut terkenal dengan julukan "Swiss van Java". Seperti keindahan alam Swiss, Garut memiliki pesona alam menakjubkan dengan kontur alam yang eksotis dan udaranya yang yang sejuk. Begitu indahnya sehingga orang-orang Belanda menyebut kota ini Mooi Garut atau Garut yang molek pada awal abad ke-20 (http://cetak.kompas.com, 4 April 2009). Dahulu kemajuan pariwisata Garut bersamaan dengan tumbuhnya perkebunan besar. Ketika itu banyak para pegawai dan pejabat perkebunan serta kolega mereka yang datang dari luar negeri memerlukan hiburan. Oleh karena itu, infrastruktur pariwisata seperti hotelhotel dibangun (Anggapraja, 1984: 165).

Potensi wisatanya tidak hanya karena keindahan alam, juga kulinernya yang khasnya, yaitu dodol garut dan berbagai jenis makanan olahan dari kulit. Selain itu, sentra kerajinan mulai dari jaket kulit hingga batik garutan berkembang dengan pesat.

Hal lain yang unik dari wilayah Garut adalah tumbuh dan berkembangnya ekonomi yang berbasis one village, one product (satu kampung, satu produk). Usaha ekonomi kreatif tersebut diwariskan dari masa ke masa dan generasi ke generasi hingga tetap lestari. Selain itu, penduduknya memiliki mobilitas yang tinggi. Perantauan dengan motif ekonomi orang Garut sama lekat dengan tetangganya, Tasikmalaya. Mereka tersebar di berbagai daerah di Jawa Barat, Jakarta, bahkan hingga provinsi lain. Meskipun demikian, ikatan komunal dengan kampung halaman tetap terjalin erat. Dalam waktu-waktu tertentu, khususnya lebaran Idul Fitri, mereka mudik ke kampung halaman. Meminjam teori Mc Clelland (Rakhmat, 1999), tipe komunitas seperti itu memiliki semangat kewirausahaan yang tinggi. Sungguh menarik, di tengah masyarakat dengan tipikal need for affiliation (keinginan untuk bersahabat, berkasih sayang, populer, disukai banyak orang) yang tinggi, ternyata memiliki need for achievement (keinginan berprestasi) yang sama kuatnya.

Masyarakat Garut termasuk dalam ranah etnopreneurship yang 
cukup mencuat peranannya di bidang ekonomi. Etnopreneurship didefinisikan sebagai suatu aktivitas perdagangan yang menggambarkan karakter suku bangsa dalam penampilan, ciri khas produk, dan dasar nilai ekonomi. Secara konseptual, etnopreneurship menyangkut hubungan antara identitas kesukubangsaan dengan wirausaha (Effendi, 2002: 229). Kajian mengenai etnopreneurship menjadi semakin penting di tengah-tengah upaya mengembangkan ekonomi kreatif yang berbasiskan tradisi. ${ }^{1}$

Penelitian tentang perkembangan sosial ekonomi Kabupaten Garut bukan saja mempelajari kondisi dan struktur kelas, tetapi juga memberi makna terhadap perubahan yang terjadi dan melihat kekuatan-kekuatan apa yang ada di belakangnnya. Sejarah ekonomi lokal sangat penting karena tiap-tiap daerah di Indonesia menempuh jalan sendirisendiri dalam perkembangan ekonomi.

Masalah pokok dari penelitian ini adalah "faktor-faktor apa saja yang menyebabkan terjadinya dinamika perkembangan sosial-ekonomi di Kabupaten Garut?" Untuk merinci masalah di atas, di bawah ini dikemukakan permasalahan sebagai berikut:

1) Bagaimana kehidupan sosialekonomi masyarakat Kabupaten Garut?

2) Apa saja wirausaha yang tumbuh dan berkembang di Kabupaten Garut?

1 Ekonomi Kreatif merupakan era ekonomi baru yang mengintensifkan informasi dan kreativitas dengan mengandalkan ide dan stock of knowledge dari sumber daya manusianya sebagai faktor produksi utama dalam kegiatan ekonominya (http://www.ristek.go.id).
3) Bagaimana tantangan dan perubahan yang dihadapi?

Sesuai dengan perumusan masalah yang telah disebutkan, maka yang menjadi maksud penelitian ini adalah untuk memperoleh deskripsi tentang petumbuhan ekonomi dan perkembangan sosial masyarakat Garut secara kronologis.

Adapun manfaat hasil penelitian ini antara lain:

1) Dari segi akademik, hasil penelitian ini diharapkan dapat memperkaya khasanah kepustakaan mengenai sejarah sosial-ekonomi.

2) Dari segi praktis, hasil penelitian ini diharapkan dapat menjadi sumbangan dalam pengembangan ekonomi kreatif dan etnopreneuship.

Ruang lingkup penelitian ini terdiri dari ruang lingkup spatial dan temporal. Secara operasional penelitian dilakukan di dua tempat di Kabupaten Garut, yaitu Kota Garut dan Kecamatan Banyuresmi. Adapun pemilihan daerah tersebut didasarkan pada konsep kota-desa dan wilayah surplus-minus. Secara temporal, penelitian ini mencakup periode yang panjang, dimulai dengan perkembangan ekonomi pada masa kolonial hingga tahun 2010.

Penelitian ini bertumpu pada metode sejarah lisan. Sejarah lisan dirumuskan James H. Morrison (2000: xiv) sebagai "pengumpulan bahan-bahan melalui perbincangan atau wawancara dengan satu orang atau lebih mengenai satu masalah yang sedang dipelajari oleh sang pewawancara". Adapun sumbangan sejarah lisan, menurut Kuntowijoyo (1994: 25), dalam mengembangkan substansi penulisan sejarah adalah sebagai berikut: 
1. Dengan sifatnya yang kontemporer sejarah lisan memberikan kemungkinan-kemungkinan yang hampir tak terbatas untuk menggali sejarah dari pelaku-pelakunya;

2. sejarah lisan mencapai pelaku-pelaku sejarah yang tidak disebutkan dalam dokumen;

3. sejarah lisan memungkinkan penulisan permasalahan sejarah yang lebih beragam, karena sejarah tidak lagi dibatasi kepada adanya dokumen tertulis.

Menurut Louis Gottschalk, metode sejarah adalah proses menguji dan menganalisis secara kritis rekaman dan peninggalan masa lampau, dengan menempuh proses rekonstruksi tentang masa lampau dan menuliskan hasilnya berdasarkan data yang diperoleh disebut historiografi (penulisan sejarah). Sementara itu, Gilbert J. Garraghan mengemukakan bahwa metode penelitian sejarah adalah seperangkat aturan-aturan dan prinsip-prinsip yang sistematis untuk mengumpulkan sumber-sumber sejarah secara efektif menilainya secara kritis, dan menyajikan sintesa dari hasilhasil yang dipakai dalam bentuk tertulis (Nur, 2001). Selanjutnya, penelitian ini menggunakan metode kualitatif historis yang terdiri dari empat tahapan, yaitu, heuristik, kritik, analisis-sintesis, dan penulisan.

\section{B. HASIL DAN BAHASAN}

\section{Latar Kehidupan Sosial-Ekonomi di Garut}

Dalam struktur sosial masyarakat Garut, etnis Cina berperan penting. Pada permulaan tahun 1950-an, orangorang Cina menjadi pedagang kaya dan makmur. Mereka menjadi bagian dari kelas menengah yang dinamis. Mereka tinggal di pusat kota sekitar Pengkolan yang merupakan wilayah pecinan. Tidak hanya orang-orang Cina, orang Arab dan Pakistan yang berdagang memenuhi kebutuhan kaum muslim. Orang-orang Arab menjual kitab-kitab, buku-buku agama, sarung, dan peci; sedangkan orang Pakistan menjual peralatan sembahyang, kain, dan pakaian. Orang Arab menetap di Garut sejak tahun 1885, sedangkan orang Pakistan sekitar tahun 1920-an. Migrasi perantau Cina ke Jawa Barat terjadi di akhir abad ke-19 (Sofianto, 2001).

Berdasarkan peta yang Pemerintah Kolonial Belanda, permukiman etnis Cina di Kota Garut sudah ada sejak tahun 1895, bahkan kelenteng sudah ada sekitar tahun 1838. Ketika itu etnis Cina bermukim di sekitar daerah Ciwalen/Sukaregang Hilir (wijkenstelsel). Pemisahan etnis Cina merupakan strategi Pemerintah Kolonial Belanda demi menghindarkan kesatuan politis di dalam masyarakat Kota Garut. Permukiman etnis Cina terpisah dari bumiputra hingga terkesan mengelompok. Pemerintah Kolonial Hindia Belanda mengangkat wijkmeester untuk mempermudah pengawasan terhadap orang Cina. Menurut istilah orang Cina disebut bek. Seorang bek bertugas mencatat jumlah penduduk Cina dalam hal kelahiran, kematian, pindah tempat tinggal, izin tempat tinggal. Ia diwajibkan menyampaikan informasi yang diperlukan oleh Pemerintah Hindia Belanda. Pada tahun 1920, wijkmeester atau bek di Kota Garut yaitu Tan Chin Liong, sedangkan sekretarisnya dari kaum pribumi adalah Ulis. Kantornya berada di Jln. Holle yang berdekatan dengan rel kereta api). Pada tahun 1940, 
Yo Tek Kun menggantikan Tan Chin Liong sebagai bek. Kemudian, kantornya dipindahkan ke Sukaregang.

Secara umum mata pencaharian etnis Cina di Kota Garut adalah berdagang. Namun, ada hal yang menarik bahwa pada permulaan kedatangannya di Kota Garut, mereka memiliki profesi yang beragam, seperti orang Hokkien berdagang, Teo-Chiu dan Hakka (Khek) kuli atau buruh, dan orang Kanton tukang (Sofianto, 2001 : 18).

Kebijakan Pemerintah Kolonial Belanda lainnya yang turut memperkuat kedudukan etnis Cina di Kota Garut adalah pemberlakukan UU Agraria tahun 1870. Undang-undang tersebut membatasi kelompok etnis Cina untuk memperoleh hak milik tanah, dengan seizin pemerintah daerah setempat. Oleh karena itu mereka tidak mungkin lagi bekerja di bidang pertanian, dan beralih menjadi pedagang. ${ }^{2}$

Pemerintah Kolonial Belanda memberikan hak istimewa kepada etnis Cina untuk menjadi leveransir (pemasok barang) bagi perkebunan-perkebunan asing yang berada di luar Kota Garut. Saat itu leveransir perkebunan di kawasan Garut adalah Toko Ek Bouw, milik Thio Tiang Tjin atau "babah gemuk"; Toko Batavia (sekarang Toko Jakarta), milik Tan Tiang Tjin; dan Toko Khoe Pek Goan milik Khoe Pek Goan. Toko Ek Bouw menyediakan barang konsumsi harian, antara lain gula, garam, minyak, tepung, dan daging. Toko Batavia menjual beras

2 Tujuan utama berdagang etnis Cina adalah memperoleh kekayaan yang lebih besar dan mencapai taraf hidup yang lebih baik sehingga apabila hendak kembali ke tanah airnya (Tiongkok) dapat membawa kekayaan hasil jerihpayahnya. dan peralatan olah raga, sedangkan Toko Khoe Pek Goan menjual roti dan kue. Sementara itu, leveransir di Cibodas yang dimiliki Joe Si Eng menjual beras dan teh.

Hak-hak istimewa yang diberikan pada orang-orang Cina di Kota Garut membuat mereka cenderung memencilkan diri dari kehidupan masyarakat pribumi. Namun dapat pula dipahami bahwa hal itu tidak lebih upaya untuk memperkuat monopoli mereka dalam bidang perdagangan. Mereka melakukan perkawinan antara kelompok mereka sendiri.

Kiprah orang-orang Arab dan Pakistan tidak dapat diabaikan. Sejak awal mereka datang ke Nusantara untuk berdagang dan menyebarkan agama Islam. Diperkirakan bahwa dua tujuan tersebut menjadi dasar kedatangan mereka di Kota Garut.

Pedagang Arab asal Hadramaut (Yaman Selatan) yang pertama menetap di Kota Garut adalah Muhammad bin Silim, Said bin Ahmad Bayasut, dan Muhammad bin Abdulah Al Habsyi. Muhammad bin Salim membuka Toko Majapahit di Jln. Groete Weg tahun 1925. Barang-barang yang dijualnya adalah tekstil/pakaian dan barabadan seperti sandal, ember, sabun, dan sikat gigi. Selainnitu, Toko Majapahit menjadi penyalur tekstil cap Padi produksi Preanger Bont Weverij (Sofianto, 2001 : 40).

Sesudah proklamasi kemerdekaan RI, terjadi perubahan barang-barang yang perdagangkan orang Arab dan Pakistan. Orang-orang Arab berdagang barang-barang kelontongan, bukubuku atau kitab-kitab Islam; sedangkan orang Pakistan berjualan kain/tekstil, 
peralatan shalat, pakaian muslim, dan batik (Sofianto, 2001 : 20).

Said bin Ahmad Bayasut pada tahun 1925 menjual sepatu, sandal, kitabkitab Islam, minyak-wangi, kemenyan, dan sebagainya. Ia membuat sendiri sepatu yang dijualnya. Pada tahun 1920an, Muhammad bin Abdulah Al Habsyi membuka Toko Al Azhar di JI. Pasar Baru yang menjual kitab-kitab, minyak wangi, kemenyan, payung, dan seterusnya. Orang-orang Arab bermukim di Kota Garut, Bayongbong, dan Sukawening.

Demikianlah kehidupan orangorang Belanda, Cina, Arab, dan Pakistan. Bertolak belakang dengan kehidupan serba makmur orang asing, pribumi hidup dengan sederhana. Mereka umumnya bekerja sebagai petani dan pedagang. Alat-alat pertanian yang digunakan, seperti garu, cangkul, dan bajak. Peranan penduduk bumiputra di bidang perniagaan tidak menonjol. Kondisi tersebut disebabkan faktor nilai dan politik yang kurang mendukung, serta persaingan dengan pengusaha Cina (Sofianto, 2001: 34-35).

Setiap hari Selasa dan Sabtu orang-orang pribumi berdagang di pasar Kota Garut. Mereka menjual buahbuahan, ikan, umbi-umbian, kelapa, ikan mas, makanan tradisional dan berbagai kerajinan rakyat. Hari pasar, bagi perempuan pribumi, menjadi hari yang spesial tidak ubahnya seperti hendak ke pesta. Kain kebaya dengan selendang, dan perhiasan mempercantik tampilan mereka. Di sekitar pasar tidak hanya mereka yang berdagang. Ada juga tukang jahit yang semakin sibuk menjelang hari raya Idul Fitri.

Perkembangan aktivitas perdagangan di Garut banyak dipengaruhi oleh peranan para pendatang. Mereka yang dianggap perintis itu adalah $\mathrm{H}$. Sirad dari Kudus, H. Mukti Ali dari Cirebon, H. Abdulah dari Pekalongan, H. Zamhari dari Kudus, H. Kamil dari Cirebon, dan H. Iton dari Cirebon. Sejak tahun 1920-an H.Sirad membuka usaha Dodol Kursinah. Pada akhir tahun 1940-an ia membuka usaha penyewaan kendaraan. H. Mukti Ali membuka usaha toko ramuramuan di J1. Ciledug. H. Abdulah pada tahun 1960-an membuka toko terbesar di Garut, yaitu Toko Merdeka. sejak tahun 1930-an, H. Zamhari membuka toko pakaian dan kain di J1. Pasar. H. Kamil membuka usaha toko kelontongan di Jagal (Sofianto, 2001: 31).

Faktorgeografissangatmenentukan bidang pekerjaan masyarakat Garut. Sebagian besar masyarakat bekerja di sektor pertanian disebabkan kesuburan tanah dan iklim yang kondusif. Hal itu juga diperkuat oleh masih rendahnya taraf pendidikan masyarakat yang tidak memberinya pilihan untuk bekerja di bidang pekerjaan dengan keahlian khusus. Selain bertani, masyarakat beternak ayam, kambing, dan kerbau.

Sebagian besar petani merupakan penggarap sawah milik orang lain. Mereka bekerja mengolah tanah, menanam, dan memanennya. Kemudian, hasilnya dibagi dua antara petani pemilik dengan buruh tani. Petani pemilik kaya yang merupakan pituin orang Garut adalah $\mathrm{H}$. Siti Menoh Mumah dan H. Dahlan.

\section{Sentra Wirausaha di Garut a. Industri Kulit Sukaregang}

Sejarah awal perkembangan kerajinan kulit Industri kerajinan kulit di Garut memiliki beberapa versi. Versi pertama menyebutkan bahwa ekonomi kreatif ini mulai berkembang sejak tahun masa penjajahan Belanda, tepatnya 
tahun 1920. Versi kedua mengatakan bahwa kerajinan ini tumbuh sejak zaman Jepang. Perintisnya adalah seorang pekerja industri penyamakan kulit di Jatayu Bandung. Ia kemudian berhasil menerapkan keterampilannya di Sukaregang. ${ }^{3}$ Versi ketiga menyebut tahun 1954 sebagai awal usaha ekonomi kreatif ini. Namun, dari berbagai pendapat tersebut terdapat persamaan bahwa perkembangan kerajinan ini sekurang-kurangnya sudah melampaui tiga generasi.

Pada mulanya pengolahan kulit dilakukan dengan teknik yang sangat sederhana. Dapat dikatakan pengolahannya dilakukan secara manual hingga dikatakan memfungsikan semua anggota tubuh dari kepala sampai kaki. Perkembangan signifikan baru sejak tahun 1987, saat dikembangkannya sistem semimodern atau semi industri pabrik, dengan penggunaan bahan kimia dari tumbuhan, lumpur, dan kapur. Pada tahun 2000 industri ini berkembang lebih maju dengan diperkenalkannya teknologi mesin yang sudah modern. ${ }^{4}$

3 Diceritakan pemilik Pabrik Kulit (PK) Arsya Leader Sukaregang, Ir. H. Ayub Afandi, dalam http://www. suararadio.com/2010/10/industri-kulitsukaregang-tetap-eksis, diakses 12 November 2010.

4 Wawancara H. Gemi, Sukaregang, 8 Juni 2010
Sentra Industri Kerajinan Kulit Sukaregang

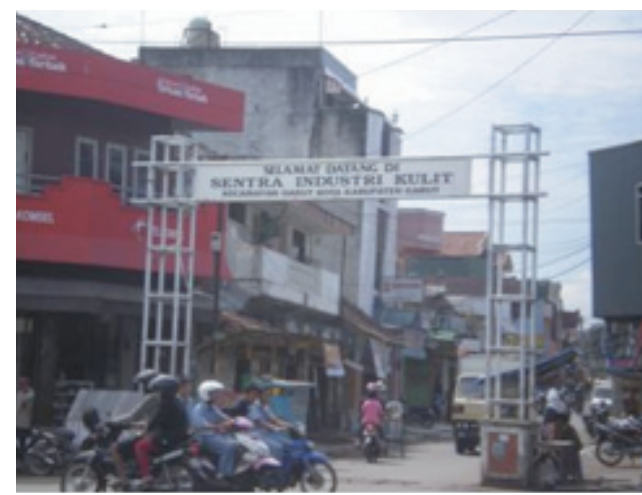

Sumber: Dok. Peneliti BPSNT Bandung

(2010)

Beberapa tokoh yang memulai pengolahan industri kulit, antara lain H. Muchtar, H. Ahmad, dan H. Ayat. Pada awalnya industri kulit merupakan industri rumah tangga. Oleh karena itu, para pekerjanya kebanyakan memiliki pertalian darah. Sebagai contoh, usaha yang dikembangkan oleh H. Ahmad. Setelah H. Ahmad meninggal, usaha diteruskan oleh H. Gemi. Keterampilan mengolah kulit umumnya diperoleh secara turun temurun dari orang tua. Sementara itu, sebagian pengusaha mendapatkan keahlian tersebut setelah bekerja bertahun-tahun di industri penyamakan kulit milik pengusaha lainnya. Oleh karena prinsipnya berdasarkan kekeluargaan, manajerialnya masih bersifat tradisional.

Keterampilan menyamak dan mengolah kulit menjadi keahlian milik bersama masyarakat Sukaregang. Sebagian besar masyarakat Sukaregang menggantungkan hidupnya dari aktivitas industri kerajinan kulit. 
Pada perkembangannya kemudian, para pengrajin baru berdatangan dari luar Sukaregang, namun masih dalam lingkup wilayah Kabupaten Garut. Pengrajin dengan latar belakang etnis Minang dan Batak turut menjadi bagian dari para pengusaha yang berkecimpung di industri tersebut.

Di Sukaregang industri penyamakan kulit dapat dikelompokkan dalam tiga kelompok. ${ }^{5}$ Pertama, industri yang memasok kebutuhan bahan baku kulit untuk industri sepatu. Biasanya bahan baku kulit untuk sepatu lebih tebal dan lebih kaku yang berasal dari kulit sapi atau kulit kerbau.

Kedua, industri yang memasok kebutuhan bahan bakukulituntukgarmen. Biasanya kulit samakan yang digunakan lebih tipis dibandingkan dengan untuk industri sepatu. Bahan mentahnya berupa kulit kambing atau kulit domba. Selain untuk garmen (seperti jaket kulit), juga dipakai untuk industri sarung tangan golf.

Ketiga, industri yang memasok kebutuhan bahan baku kulit untuk industri sarung tangan kerja (working gloves). Bahan mentahnya dari hasil split atau seset dari kulit sapi atau kulit kerbau.

Selain ketiga jenis sentra industri penyamakan kulit tersebut, masih ada sentra industri kerupuk kulit. Biasanya bahan bakunya berupa kulit sapi atau kulit kerbau.

Aktivitas ekonomi kreatif ini mengalami masa-masa emas sebelum tahun 1997.Ketikaituterdapatkuranglebih

5 "Endies Leather Company, Memasok Bahan Baku Kulit Berkualitas Hingga ke Mancanegara", dalam Majalah Kina (No.5-2007) Departemen Perindustrian RI enam ratusan pengusaha kerajinan kulit. Krisis moneter yang melanda Indonesia memberi pengaruh negatif terhadap perkembangan ekonomi nasional. Ekonomi berskala besar, menengah, dan kecil mengalami kegoncangan. Kondisi tersebut berdampak pada kelesuan di bidang industri kulit.

Produksi mengalami penurunan drastis, karena minimnya permintaan dan meningkatnya biaya produksi. Selain faktor yang timbul dari dalam, ada pula faktor luar yang turut melemahkan industri tersebut. Bantuan dan pembinaan Pemerintah Daerah berkurang disebabkan keterbatasan anggaran. Pada tahun 1997 kegiatan pembinaan dan jasa layanan mesin-mesin UPT Sukaregang menurun oleh karena keterbatasan dana operasional. Akhirnya, tahun 2000 UPT Sukaregang berhenti total dengan melelang mesin-mesin untuk pesangon karyawannya. Sejak tahun 2000 hingga tahun 2003 UPT Sukaregang mengalami kevakuman dalam kegiatan pembinaan. Akan tetapi, di sisi lain industri kulit ini memperlihat daya hidupnya dengan terus berkembang dan tumbuh pengusaha yang menyewakan mesin-mesin.

Pada tahun 2001 Pemerintah Daerah Kabupaten Garut melalui bantuan Bank Dunia memanfaatkan lahan dan bangunan UPT untuk mesinmesin Leather Board dari limbah serutan kulit. Sementara itu, Dinas Lingkungan Hidup dan Kebersihan bekerjasama dengan Kementrian Lingkungan Hidup memanfaatkan sebagian bangunan UPT untuk kegiatan SIK dan Instalasi Recovery Chroom. pada tahun 2001 di Sukaregang terdapat 330 unit usaha penyamakan kulit yang memperkerjakan 1.495 tenaga kerja. Sementara jumlah produksi kulit tersamak mencapai 
7.659,25 ton. Pada tahun 2004 Balai pengembangan Perindustrian Jawa Barat mengaktifkan kembali UPT Sukaregang dengan merenovasi gedung, pemagaran, pengadaan mesin untuk layanan kepada penyamak dan pengrajin barang dari kulit (Cahyana, 2007: 4). Dalam sepuluh tahun terakhir tercatat industri rumah tangga yang bergerak di bidang kerajinan kulit berjumlah 420, dengan karyawan sekitar 2000 orang.

Hasil kerajinan kulit Sukaregang tidak saja diserap pasar domestik, tetapi juga ke mancanegara, seperti Cina, Thailand, Singapura. Dari omset kimia saja mencapai 2 miliar per tahun. Sistem dagangnya dilakukan dengan dua cara, yaitu ritel dan partai.

Sebagai upaya mengeratkan silaturahmi dan memberi dukungan antar sesama pengusaha kulit dibentuklah APKI (Asosiasi Pengusaha Kulit Indonesia) tahun 2006. Pengusaha yang ditunjuk menjadi ketua APKI adalah H. Uway, dengan wakilnya Nanang Ruswandi. Dalam aktivitasnya, APKI tidak mengontrol anggota yang tergabung di dalamnya. Selain APKI, ada pula Forum Komunikasi Pengusaha Kulit Garut yang lebih bersifat informal. ${ }^{6}$

Para pelaku industri penyamakan kulit di Sukaregang memperoleh kemudahan dalam memperoleh bahan baku kulit mentah. Pemerintah membuka kran impor kulit setengah jadi seperti wet blue dan pickle. Meskipun demikian, impor terbatas untuk kulit kambing dan domba. Bahan baku kulit sapi masih sulit diperoleh. Ironisnya, bahan baku berupa kulit sapi atau kulit kerbau mentah domestik diekspor ke luar negeri. Kulit

6 Wawancara H. Gemi, Sukaregang, 8 Juni 2010 sapi Jawa laku keras di pasar ekspor, karena diminati pasaran internasional.

Sentra industri kulit di Sukaregang telah berkembang menjadi klaster industri yang mapan, mulai dari industri hulu berupa industri penyamakan kulit hingga industri hilir berupa industri kerajinan sepatu, jaket, tas, dompet, topi ikat pinggang, dan lain-lain. Industri kulit Sukaregang menjadi cerminan industri rakyat yang mandiri, mampu bertahan dan menghidupi banyak orang.

\section{b. Batik Tulis Garutan}

Eksistensi Batik Tulis Garutan memiliki perjalanan sejarahyangpanjang. Diceritakan bahwa pada akhir abad ke19, KF Holle, juragan perkebunan teh Waspada di Cikajang membuka industri batik di perkebunannya. Dalam buku Garoet en Omstreken (1921) tentang panduan perjalanan wisata bagi turisturis asing disebutkan pada tahun 1920an Batik Garutan sudah dijadikan buah tangan khas Garut. Ayu Iti bersama suaminya Muksan (putra H. Sirad) di JI. Gunung Lumbung sejak tahun 1930-an mengusahakan industri rumah tangga kerajinan batik. Kerajinan batik yang diproduksinya dikenal dengan nama batik garutan. Batik garutan itu selain sangat terkenal di daerah Priangan, juga terkenal, baik bagi para wisatawan mancanegara maupun domestik.

Pada tahun 1940-an ada laporan bahwa Batik Garutan telah dipasarkan. Pada tahun 1945 Batik Garut semakin dikenal dengan sebutan Batik Tulis Garutan. Batik Garut semakin berkembang tahun 1979 .

Antara tahun 1967 s.d. 1985 merupakan masa kejayaan Batik Garutan. Saat itu terdapat 126 unit usaha pembatikan. Dalam perkembangan 
berikutnya, produksi Batik Garutan mengalami penurunan. Adapun faktorfaktor yang menjadi penyebabnya, antara lain berkembangnya batik printing atau batik cap, kurangnya minat generasi penerus pada usaha batik tulis, ketidaktersediaan bahan dan modal, serta lemahnya strategi pemasaran.

Batik Garutan diminati konsumen mancanegara, seperti Belanda, Jepang, dan Cina. Pada mulanya batik diproduksi hanya untuk memenuhi pesanan. Namun, sekarang batik tulis diproduksi secara besar-besaran. Produk Batik Garut antara lain kain untuk perempuan, kemeja pria, tutup meja, sprei, dan tas.

Ciri yang mencolok dari batik Garutan adalah warna biru dan merah dengan warna coklat muda (krem) sebagai latar belakangnya. Batik Garutan didominasi pola geometri yang disajikan secara diagonal dengan motif tumbuhan bambu dan bunga. Ornamen Batik Garutan dipengaruhi motif batik Cirebon, Yogya, Solo, dan Cina. Batik garutan umumnya digunakan untuk kain sinjang dan berfungsi untuk memenuhi kebutuhan sandang.

Salah satu toko Batik Garutan

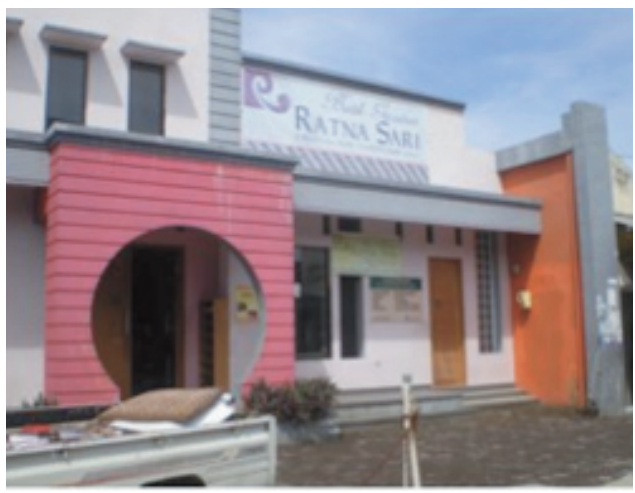

Sumber: Dok. Peneliti BPSNT Bandung (2010)
Bentuk motif batik Garut mencerminkan kehidupan sosial budaya, falsafah hidup, dan tradisi orang Sunda. Secara visual perwujudan batik Garut digambarkan dalam motif dan warnanya. Bangun geometris menggambarkan topografi Garut yang bergunung-gunung. Garis-garis diagonal menggambarkan jalan yang miring menanjak. Kawung atau belah ketupat merujuk posisi gunung di sekitar Garut yang menempati empat penjuru angin. Bangun belah ketupat merupakan variasi dari bentuk gunung dan bukit yang mirip dengan bangun segitiga.

Selain bangun geometri, ada pula batik garut bermotifkan anyaman. Tekanannya yang tajam tampak pada gambar bunga atau tumbuhan. Pada Gambar 5, bentuk benda sehari-hari (payung) terlihat dengan jelas. Bentuk semacam ini menunjukkan hubungan yang lekat dengan alam. Analisis fraktal menunjukkan dimensi batik Garut berkisar antara 1,3 dan 1,4. Pola-pola semacam ini memperkuat dugaan bahwa motif batik Garut masih sangat asli dan alami.

Beberapa pengusaha Batik Garutan, antara lain $\mathrm{Hj}$. Odah di Kampung Sisir, Bapak Suhanda (Batik Famili), ibu Ayu Epon (Cikendi), dan ibu Nani (Batik Tulen). Sebagaimana dituturkan $\mathrm{Hj}$. Odah, keahlian membatik dan memasarkannya diperoleh dari nenek. ${ }^{7}$ Mula-mula neneknya membatik di Sukaregang dan Ciledug. Ketika itu pemasarannya sudah sampai ke Jakarta, Bogor, Bandung, dan Semarang. Adapun wadah yang menaungi para pengusaha

7 Wawancara $\mathrm{Hj}$. Saodah (Kampung Sisir, Garut, 8 Juni 2010 
batik adalah PKBI(Perhimunan Koperasi Batik Indonesia). ${ }^{8}$

\section{c. Tukang Cukur dari Kecamatan Banyuresmi}

Salah satu keunikan dari karakteristik kewirausahaan orang Garut adalah semangat merantau yang mereka miliki. Mereka tersebar di berbagai wilayah di Indonesia, khususnya di kota-kota besar. Ada yang merantau ke Bandung, Bekasi, Jakarta, Tangerang, dan lain-lain. Secara umum mereka bekerja sampai ke tempat yang jauh, dan kembali pada saat-saat tertentu. Faktor pendorong yang menyebabkan mereka bekerja di luar kampung halamannya adalah masalah ekonomi. Sementara ini dapat dijelaskan bahwa faktor demografis dan terbatasnya lahan pekerjaan menjadi faktor yang utama. Hal ini bukanlah khas orang Garut saja. Akan tetapi generalisasi semacam ini tentu harus dilihat lebih mendalam sehingga didapatkan sebabsebab yang lebih akurat.

Salah satu profesi tradisional orang Garut di tanah rantau adalah tukang cukur (paras). Keberadaan mereka tersebar di kota-kota di Jawa Barat. Diperkirakan jumlahnya mencapai ribuan. Pelanggan mereka berasal dari berbagai kalangan, mulai masyarakat yang biasa yang dicukur di bawah pohon hingga Presiden Susilo Bambang. Desadesa penghasil tukang cukur sebagian besar berada di Kecamatan Banyuresmi. Secara spesifik desa-desa itu adalah Parung, Bagendit, Bantarjati, Pasirsalam, Pendeuy, Sargenteng, Balakasap, dan Aurseah.

Desa Parung Kecamatan Banyuresmi merupakan daerah yang

8 Wawancara $\mathrm{Hj}$. Saodah (Kampung Sisir), Garut, 8 Juni 2010 sejak lama dikenal sebagai "kampung tukar cukur" . Desa Parung terdiri dari 4 RT dan2 RW, dengan 144 Kepala Keluarga. Jumlah penduduk Desa Parung sekitar 4875 orang. Profesi tersebut mulai berkembang sekitar tahun 1970an. Profesi ini mampu memberikan kesejahteraan bagi penduduk kampung tersebut. Hasil dari perantauan, mereka membangun rumah permanen yang lebih baik. Apabila sesekali berkunjung ke kampung yang berjarak $12 \mathrm{~km}$ dari kota Garut terlihat perbedaan antara desa tersebut dengan desa-desa di sekitarnya. Umumnya rumah-rumah di Kampung Parung relatif lebih bagus. Agaknya profesi tukang cukur menjadi berkah tersendiri bagi penduduk kampung ini. Dahulu Parung mendapat julukan “Kampung Dolar". ${ }^{9}$ Julukan tersebut merujuk pada peningkatan kesejahteraan penduduk kampung Parung. Sebagian hasil bekerja di perantauan dikirimkan ke keluarga di Banyuresmi. Uang tersebut cukup membiayai kebutuhan sehari-hari, sekolah anak, dan membeli kendaraan. Bahkan pembangunan masjid dan perbaikan jalan pernah dibiayai dari hasil patungan para tukang cukur Jabodetabek. ${ }^{10}$
9 Wawancara Ade Kanta, Banyuresmi, 7 Juni 2010

10 "Desa Bagendit, Daerah Penghasil Ribuan Tukang Cukur”, http:// datahardisk.blogspot.com/2010/06/ desa-bagendit-daerah-penghasil-ribuan. html. 
Gerbang menuju

Kampung Parung

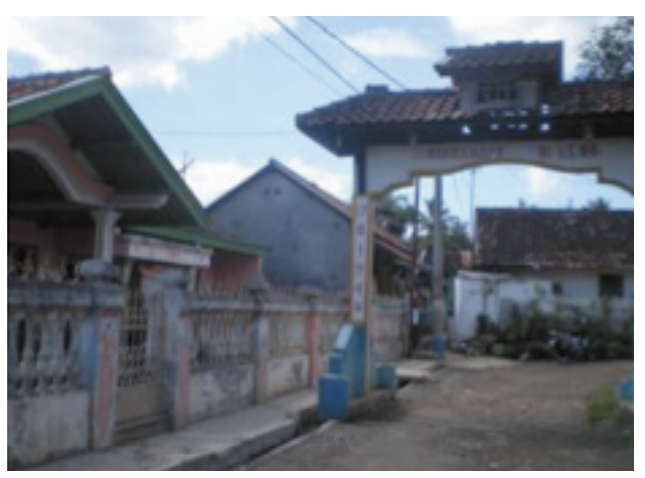

Sumber: Dok. Peneliti BPSNT Bandung (2010)

Apabila disebutkan tahun 1970-an sebagai periode perantauan para tukang cukur ini, sebenarnya ada informasi yang menyebutkan lima belas tahun lebih dahulu. Menurut keterangan Bapak Engkus Kosasih (60 tahun), para perantau ini sudah ada pada tahun 1955. Para pemuda yang berasal dari Parung biasanya memiliki keahlian mencukur. Dalam setiap rumah di Parung selalu saja ada yang memiliki keahlian mencukur. Oleh karena itu, selepas SD atau SLTP, mereka merantau ke luar kampung supaya dapat hidup mandiri.

Ada pula kisah lain tentang permulaan rantau tukang cukur di tahun 1950 -an. Diceritakan waktu itu para pria asal Garut usia 16-25 tahun bekerja ke Jakarta menjadi tukang bangunan. Hal tersebut dipicu oleh pesatnya proyek konstruksi di Ibu Kota. Bakur, salah seorang pemuda Garut yang bekerja, membuka usaha pangkas rambut dengan alat cukur sederhana. Di bawah pohon rindang, Bakur mencukur para pekerja bangunan. Ternyata cukup banyak para pekerja yang menjadi langganannya.
Lalu, ia mengajak teman-temannya dari Bagendit untuk menjadi tukang cukur. Kesuksesan Bakur memicu eksodus para pemuda pencukur untuk mengadu nasib ke Jakarta.

Para orang tua yang sudah bertahun-tahun merantau kembali dan tinggal di kampung mengelola sawahsawah yang sebagian ditinggalkan para pekerja mudanya yang merantau tersebut. Pekerjaan mencukur dilanjutkan dari generasi ke generasi. Para pemuda tersebut akan kembali ke kampungnya setiap dua bulan sekali, dan kemudian bekerja kembali. ${ }^{11}$

Keahlian mencukur lebih merupakan proses pengalaman yang dilalui. Tradisi mencukur tidak selalu berasal dari keluarga para tukang paras. Ada juga mereka yang belajar dari lingkungan sekolah atau temantemannya.

Pewarisan keahlian mencukur di Banyuresmi melalui satu mekanisme yang disebut ngider nyukur atau tradisi ngampung. Tukang cukur pemula mengikuti semacam proses magang. Biasanya tukang cukur senior membawa juniornya mencari target di kampungkampung terpencil. Tidak mudah mendapat sasaran uji coba. Alat cukur yang dibawa hanya gunting dan sisir, tanpa cermin. Target latihan biasanya anakanak SD atau SMP. Mereka membawa bangku. Mesinnya menggunakan ketek. Barulah tahun 90-an memakai tones.

Ketika tukang cukur junior menemukan targetnya. Tukang cukur senior cukup mengawasi saja, tanpa memberi petunjuk. Setelah junior selesai mencukur, seniornya yang akan

11 Wawancara Engkus Kosasih, Banyuresmi, 7 Juni 2010 
merapihkan. Target yang dicukur tentu tidak mengetahui hasilnya, karena tidak ada cermin. Inilah 'bangku sekolah' yang harus dijalani oleh para pemula. Semakin sering mencukur dalam proses magang ini akan semakin terasah keahlian mencukur.

Proses ini dijalani selama 3 bulan sampai 6 bulan. Bagi para pemula, meski ia telah menguasai teknik mencukur yang baik, penentu keberhasilan adalah nyali yang dimilikinya. Setelah dinyatakan mampu, junior diajak merantau untuk menjalani profesinya sebagai tukang cukur yang sesungguhnya. Mereka menyiapkan semua perlengkapannya sendiri, dari gunting, bedak, sisir, pisau cukur, sapu, pemotong rambut listrik, dan sabun wangi.

Para junior yang sudah mengikuti seniornya bekerja di kota, dalam waktuwaktu tertentu kembali ke kampung. Hal tersebut dimaksudkan untuk semakin mengasah keterampilan mencukur. Mereka kembali berkeliling mencari anak-anak yang siap dijadikan objek para junior tersebut. ${ }^{12}$

Tidak semua para tukang cukur setelah melalui tradisi ngider nyukur merantau ke kota. Ada pula tukang cukur yang cukup nyaman untuk tetap bekerja dengan cara berkeliling. Bahkan ada diantara mereka yang menjalani pekerjaan tersebut selama puluhan tahun.

Walau para tukang cukur perantau ini berasal dari kampung, mereka mengikuti tren potongan rambut. Tren rambut mulai gaya rambut polka, cepak, golep sahedeng (ala Mandarin), hingga

12 Wawancara Renal, Bandung, 15 Desember 2010. Renal adalah tukang cukur yang berasal dari Cimareme Kecamatan Banyuresmi. bentuk skin head dapat dimintakan pada tukang cukur tersebut. Permintaan tersebut tidak saja datang dari para pemuda usia 20-an. Kadang-kadang ada juga pria dewasa berusia lanjut yang menggemari gaya potongan rambut yang sedang digemari anak muda. Tukang cukur biasanya memiliki kemampuan membaca kepribadian dan mencukur sesuai harapan pelanggan. Bahkan ia menyarankan pada pelanggan, potongan rambut terbaik.

Tukang paras asal Banyuresmi dicirikan dengan sikapnya yang ramah dalam melayani pelanggan. Mereka tidak tergesa-gesa memangkas rambut. Falsafah yang mereka hayati, yaitu lalaunan asal rapih (pelan-pelan rapi).

Selama proses memangkas, mereka memulai pembicaraan dengan pelanggan. Apabila terkesan bahwa pelanggan kurang nyaman, mereka mengalihkan pembicaraan ke topik yang secara umum digemari. Berbagai topik mereka bicarakan mulai dari soalsoal politik aktual, informasi kampung halaman, dan olahraga. Oleh karena itu, mereka memantau perkembangan yang terjadi melalui media elektronik, seperti televisi dan radio.

Salah satu ciri khas dari pemangkas rambut asal Banyuresmi adalah servis pijat di bagian kepala dan pundak selama 5 menit. Biasanya untuk pelanggan tetap, ada penambahan waktu pemijatan disesuaikan dengan keinginan yang bersangkutan. Secara umum tarif Pencukur rambut asal Banyuresmi memiliki standar yang tidak jauh berbeda. Ongkos sekali cukur di kios dan di bawah pohon antara Rp 5.000 sampai Rp 7.000. Pekerjaan optimal dari tukang cukur kadang-kadang membuat pelanggan memberikan uang tambahan. Pendapatan 
tukang cukur per bulan bervariasi antara 1 hingga 1,5 juta per bulan. Biasanya dari jumlah tersebut antara $\mathrm{Rp} 700$ ribuhingga 1 juta dikirimkan ke kampung. Apabila diestimasikan bahwa ada 2000 orang tukang cukur di Kecamatan Banyuresmi mengirimkan uang minimal Rp 500 ribu, berarti per bulan mencapai Rp1 miliar.

Tukang cukur memiliki kebanggaan apabila pelanggannya para pejabat penting, mulai dari menteri hingga presiden. Kabarnya, tukang cukur Presiden RI Susilo Bambang Yudhoyono (SBY) berasal dari Desa Bagendit. Di rantau, tukang cukur senior yang merintis usahanya di suatu daerah dianggap dunungan oleh para pemula. Misalnya, Haji Ii memiliki 10 tempat pangkas "Adil" di Cikampek. Para pemula bekerja padanya. Ia dianggap dunungan oleh para pemula tersebut. Dunungan tidak turut mencukur, hanya menerima uangnya. ${ }^{13}$ Selain pangkas "Adil", ada pula pangkas "Mahkota" yang mencapai keberhasilan di rantau dengan membuka beberapa cabang tempat cukur. Kebanyakan tukang paras asal Banyuresmi memakai label "Asgar".

Pada lebaran 2010, para tukang cukur perantau asal Garut, khususnya Kecamatan Banyuresmi, melakukan mudik massal. Kebiasaan tersebut berlangsung setiap tahunnya. Mudik merupakan satu ekspresi kultural masyarakat Garut sekaligus ajang untuk menunjukkan prestasi-prestasi sosial ekonomi yang telah diraih. Banyaknya para tukang cukur yang hendak mudik, terlihat dari banyaknya armada angkutan yang disiapkan. Tidak kurang dua puluh bis membawa pemudik tersebut yang

13 Wawancara Ade Kanta, Banyuresmi, 7 Juni 2010 hendak pulang kampung itu. Bahkan sebuah partai besar turut mensponsori kepulangannya. ${ }^{14}$

\section{PENUTUP}

Dari tiga objek telitian, ada beberapa temuan yang dapat dikemukakan. Kerajinan kulit Sukaregang, Batik Garutan, dan profesi tukang Cukur diwariskan secara turuntemurun yang bersifat kekeluargaan. Mereka secara adaptif melakukan kreasi yang disesuaikan dengan perkembangan zaman. Memang ada hal-hal tertentu yang bersifat tetap, dan adapula yang sudah disesuaikan dengan kemajuan. Namun dalam kasus kerajinan kulit Sukaregang terlihat jelas bahwa ketika bersentuhan dengan teknologi modern, ada orang-orang baru dengan latar etnik berbeda masuk ke dalamnya. Orang-orang baru ini relatif memiliki modal yang cukup dengan kemampuan manajerial yang lebih baik. Tidak sedikit dari pengusaha lama yang mengalami kelesuan dalam bisnisnya, bahkan mendekati kebangkrutan. Sementara, para pendatang makin memperkuat posisinya. Hal ini berbeda dengan Batik Garutan yang lebih bersifat elitis, sedikit sekali orang-orang baru yang terlibat dalam dunia perbatikan. Hal ini dapat dipahami karena usaha ini cenderung berangkat dari budaya priyayi. Batik garutan setidaknya merupakan pantulan dari hasrat kultural, bukan hanya menggambarkan kebudayaan Sunda, tetapi juga berupaya menemukan kembali (reinventing) nilai-nilai kesundaan yang terus memudar. Industri kulit Sukaregang dan Batik Garutan tumbuh

14 Wawancara Ade Kanta, Banyuresmi, 7 Juni 2010 
dalam kultur kota yang lebih modern dan mengharuskannya melakukan adaptasi terhadap kemajuan teknologi dan kemauan pasar. Dalam kasus yang ketiga, profesi tukang cukur memperlihatkan semangat perantauannya. Kehidupan di kampung yang semakin sulit membuat mereka mencari penghidupan di luar kampungnya. Motivasi ekonomi agaknya mendorong mereka menyebar ke berbagai wilayah untuk mencukupi kebutuhan diri dan keluarganya. Dari ketiga bidang usaha tersebut, ada kesetiaan melanjutkan apa yang sudah dikerjakan generasi sebelumnya.

Masyarakat Garut tergolong ke dalam kelompok masyarakat dengan semangat enterpreuneurship yang tinggi. Inilah modal sosial yang harus dikembangkan lebih lanjut. Garut tidak hanya memiliki keunggulan komparatif, tetapi juga keunggulan kompetitif. Potensi tersebut apabila dikelola dengan cerdas dapat memajukan kehidupan masyarakatnya. Di samping, itu dengan watak kewirausahannya itu, masyarakat Garut dapat berada di garis depan dalam menyumbangkan gagasan terhadap "Indonesia Kreatif".

Penelitian ini barulah studi pendahuluan yang memerlukan penelitian lanjutan. Sebagai kajian awal, penelitian ini hanya mengungkap garis besar perkembangannya saja. Oleh karena itu, sejumlah ruang kosong harus diisi dengan data yang lebih mendalam dari lapangan.

Spirit dari semangatkewirausahaan masyarakat Garut harus disosialisasikan secara luas. Apabila hanya sebatas kajian, tidak akan banyak gunanya untuk menghadapi tantangan yang semakin berat. Masyarakat Garut berpotensi memajukan dirinya dengan kekuatan sendiri dilandasi kekhasan tradisinya.

\section{DAFTAR SUMBER}

\section{Buku dan Artikel}

Cahyana. Indra. 2007.

Peran Pemerintah Daerah dalam Mengembangkan Klaster Industri Kulit di Kabupaten Garut. Tugas Akhir. Semarang: Fakultas Teknik UNDIP.

Effendi, Nursyirwan. 2002 . "Etnopreneurship diTanahMelayu: Kasus di Kota Pekanbaru", dalam Sastri Yunizarti Bakry dan Media Sandra Kasih, Menelusuri Jejak Melayu-Minangkabau. Padang: Yayasan Citra Budaya Indonesia, hlm. 229-248.

"Endies Leather Company, Memasok Bahan Baku Kulit Berkualitas Hingga ke Mancanegara”, dalam Majalah Kina (No.5-2007) Departemen Perindustrian RI.

Kuntowijoyo. 1994.

Metodologi Sejarah. Yogyakarta: Tiara Wacana.

Martson, Doris Riker. tt.

Sebuah Pedoman untuk Menulis Sejarah. Writer's Digest, Cincinatti, Ohio.

Nur, Muhammad.

"Metodologi dalam Ilmu Sejarah dan Pendekatan Sejarawan”. Historia: Jurnal Pendidikan 
Sejarah, No. 4, Vol. II (Desember 2001).

Rakhmat, Jalaluddin. 1999.

Rekayasa Sosial: Reformasi atau Revolusi? Bandung: Rosda.

Sofianto, Kunto. 2001.

Garut Kota Intan: Sejarah Lokal Kota Garut Sejak Zaman Kolonial Hingga Masa Kemerdekaan. Jatinangor: Alqaprint.

\section{Internet}

"Desa Bagendit, DaerahPenghasil Ribuan Tukang Cukur", http://datahardisk. blogspot.com/2010/06/desabagendit-daerah-penghasil-ribuan. html, diakses tanggal 12 Agustus 2011.

Makhasin, Luthfi.

Islamisasi dan Masyarakat Pasar: Sufisme dan Sejarah Sosial Kota Sokaraja, dalam http://lafadl. wordpress.com, diakses 10 Maret 2011.

"Perkembangan Ekonomi Kreatif di Indonesia", dalam http://www. ristek.go.id, diakses tanggal 2 November 2011.

"Swiss van Java", dalam http://cetak. kompas.com, diakses tanggal 4 April 2009.

\section{Informan}

1. Hj. Saodah, Ciledug

2. H. Gemi, Sukaregang

3. Ade Kanta, Bagendit

4. Engkus Kosasih, Parung

5. Renal, Bandung 